\title{
Anlatı Oyun Pedagojisi: Erken Çocukluk Eğitiminde Oyun Temelli Bir Yaklașım
}

\author{
Zeynep Fulya TEMEL', Aslı TEMiz ÇAĞLAR ${ }^{2}$
}

\begin{abstract}
Öz: Bu çalışmada Finlandiya'da geliştirilmiş olan oyunun gücünü ve yetişkin çocuk ortaklığını savunan Anlatı Oyun Pedagojisi (Narrative Play Pedagogy) tanıtılmıştır. Çalışma kapsamında yaklaşımın teorik ve felsefi temellerine, eğitim ortamına, yetişkin rollerine, günlük eğitim akışına, planlama, uygulama ve değerlendirme sürecine ilişkin bir kavramsal çerçeve çizilmeye çalışılmıştır. Anlatı Oyun Pedagojisi, Hakkarainen ve Bredikyte tarafından 1990'lı yılların sonunda geliştirilmiştir. Teorik ve felsefi temelleri büyük oranda Kültürel Tarihsel Kurama ve Profesör Vasili Davydov ve ekibinin ileri sürdügü görüşlere dayanmaktadır. Bu yaklaşımda çocuk oyunlarını geliştirme, genişletme ve oyun ile öğrenme hedefleri arasındaki geçişi kolaylaştırma amaçlanmıştır. Uygulamalar, çocuğu oyuna davet eden okul içi ve okul dişı çeşitli öğrenme ortamlarında yürütülür. Çocuklar anlatı oyun dünyalarında farklı yaşlardaki akran grupları ve yetişkin oyun ortakları ile hayali roller üstlenerek maceralar yaşarlar. Anlatı Oyun Pedagojisi, Türkiye'de okul öncesi eğitim kurumlarında oyun kültürünü geliştirmek için ilham verici bir örnek olarak uzmanlara ve uygulayıcılara yol gösterici olabilir.
\end{abstract}

Anahtar Sözcükler: Erken çocukluk eğitimi, Anlatı oyun ve öğrenme, Anlatı oyun pedagojisi

\section{Narrative Play Pedagogy: A Play-Based Approach to Early Childhood Education}

\begin{abstract}
This study introduces the pedagogy of narrative play, a method developed in Finland to preserve the power of play and support adult-child partnerships. It attempts to design a conceptual framework encompassing the theoretical and philosophical foundations of the approach, the educational environment, roles discharged by adults, daily flow, planning, implementation and evaluation process. Hakkarainen and Bredikyte developed the narrative play pedagogy in the late 1990s. Essentially, this methodology is theoretically and philosophically grounded in Vygotsky's cultural-historical theory of development and the opinions expressed by Professor Vasili Davydov and his team. This approach aims to devise games for children and facilitate the transition between play and school learning tasks. The pedagogy is practised in varied in-school and out-of-school environments that invite children to play. Children experience adventures in fictional worlds, playing imaginary roles with peers of different ages as well as adults as their acting partners. Narrative play pedagogy can guide experts and practitioners and represents an inspiring example of constructing a game-based learning culture in preschool education institutions in Turkey.
\end{abstract}

Keywords: Early childhood education, Narrative play and learning, Narrative play pedagogy 
Erken çocukluk döneminde oyun; çocuğun doğal gücü ve gelişimsel ilerlemesi için etkili bir araç olarak görülür. Ancak günlük yaşantıyı önemli bir şekilde değiştiren dijitalleşme (Sandberg ve PramlingSamuelsson, 2003; Elkind, 2008) ve erken dönemde akademik becerileri destekleme yönündeki eğilim (Miller ve Almon 2009) çocuğun serbest oyununu tehdit etmektedir. Elkind (2008) çocukların son yirmi yılda haftada 8 saat kadar serbest oyun zamanını kaybettiklerini vurgulamıştır. Yapılan araştırmalar (Miller ve Almon 2009; Tuğrul, Metin-Aslan, Ertürk ve Altınkaynak, 2014) öğretmenlerin ilkokula hazırlık ve müfredatı yetiştirme gibi çeşitli kaygılar nedeniyle eğitim programlarında akademik görevlere daha çok yer verdiğine işaret etmektedir. Oysa serbest oyun; çocuğun fiziksel, sosyal, duygusal ve bilişsel açıdan refahı için oldukça önemlidir (Burdette ve Whitaker 2005). Serbest oyunun çocuğa sunduğu özgür seçim firsatları çocukların kontrol becerileri kazanmalarını, öz düzenleme yapmalarını ve kendi öğrenmelerini yönlendirmelerini teşvik eder (Wood, 2014).

Gelişime uygun erken çocukluk eğitim programlarının temel koşullarından biri "oyun temelli" olmalarıdır (Bredekamp, 2015). Okul öncesi eğitim ortamlarında oyun yoluyla öğrenme deneyimlerini destekleme ve geliştirme için oyun ile pedagojiyi birleştiren oyun pedagojisi girişimleri, eğitimcilere uygulamaya yönelik yol gösterici araçlar sunar (Farne, 2005; Hakkarainen ve Bredikyte, 2020; Rogers, 2010; Wood, 2009). Eğitimcilerin oyun temelli etkinlikler için hazırlık yapmasını, oyun ortamlarını düzenlemesini, oyunu destekleyici ve geliştirici pedagojik stratejiler kullanmalarını içerir (Wood, 2004). Eğitimcilerin farklı oyun pedagojileriyle tanıştırılması oyunu desteklemeye yönelik pedagojik repertuarlarını genişletmelerine ve sınıf uygulamalarını zenginleştirmelerine katkı sağlayabilir (Ryan ve Northey-Berg, 2014; Wood, 2009). Farklı ülkelerde geliştirilen yenilikçi oyun pedagojisi yaklaşımlarının araştırılması ve incelenmesi Türkiye' deki okul öncesi eğitim uygulamaları için ilham verici olabilir. Bu doğrultuda bu çalışmada oyun temelli erken çocukluk eğitim programlarının özgün bir örneği olan, "Anlatı Oyun Pedagojisi (Narrative Play Pedagogy)" tanıtılmaya çalışılmıştır. Türkiye'deki alan yazın incelendiğinde anlatı oyun pedagojisine odaklanan bir çalışmaya rastlanmamıştır. Bu nedenle bu çalışmanın oyun pedagojisiyle ilgili Türk alan yazınına önemli bir katkı sağlayacağı düşünülmektedir.

Anlatı Oyun Pedagojisi, Hakkarainen ve Bredikyte tarafından 1990'lı yılların sonunda Finlandiya' da geliştirilmiştir. Hakkarainen ve Bredikyte tarafından yapılan çalışmalar incelendiğinde bu yaklaşıma ilişkin farklı isimlendirmeler kullandıkları görülmektedir. Bunlar; “Anlatı Oyun ve Öğrenme Yaklaşımı (Narrative Play and Learning Approach)", "Anlatı Oyun Yaklaşımı (Narrative Play Approach)", "Gelişimsel/Anlatı Oyun Pedagojisi (Developmental (Narrative) Play Pedagogy), ve "Anlatı Oyun Pedagojisidir (Narrative Play Pedagogy)" (Bredikyte ve diğerleri, 2017; Bredikyte ve Hakkarainen 2017; Hakkarainen ve Bredikyte, 2018). Bu çalışmada Anlatı Oyun Pedagojisi (Narrative Play Pedagogy) ifadesi kullanılmıştır. Anlatı oyun pedagojisi okul öncesi dönemde oyunun kalitesini geliştirmeyi ve oyun ile öğrenme hedefleri arasında geçici bir etkinlik sistemi oluşturmayı amaçlamıştır (Hakkarainen ve Bredikyte, 2018). Yaklaşım; teorik alt yapısı ve felsefi temelleri, yetişkin rolleri, fiziksel çevre, günlük eğitim akışı, planlama, uygulama ve değerlendirme süreci, başlıkları altında açıklanmıştır.

\section{Teorik Alt Yapısı ve Felsefi Temelleri}

Anlatı oyun pedagojisinin ortaya çıkışında, Hakkarainen ve Bredikyte' in 1990'larda Profesör Vasili Davydov ile birlikte yazmış oldukları bir çalışma önerisi etkili olmuştur. Bu çalışma bağlamında Profesör Vasili Davydov ve onun ekibinde yer alan Hakkarainen ve Bredikyte okul öncesi eğitimi üzerine teorik çalışmalar yapmış ve küçük çocukların gelişimsel ve eğitimsel ihtiyaçlarına odaklanmıştır. Okul öncesi eğitim kurumlarında çocuklar için bir dünya yaratmanın gerekliliği ve bunu oluşturmanın yolları üzerine tartışmalar yürütmüştür (Hakkarainen ve Bredikyte, 2020). Ayrıca "çocuk oyununun gelişimsel potansiyeli ve bu potansiyeli en üst sınırlarına çıkarabilmenin yollarını" sorgulamıştır (Hakkarainen ve Bredikyte, 2018, s.1042). $\mathrm{Bu}$ doğrultuda anlatı oyun yaklaşımı Davydov ve ekibinin ileri sürdüğü teorik ve analitik sorunları çözme girişimi olarak başlamıştır (Hakkarainen ve Bredikyte, 2020).

Anlatı oyun pedagojisi Vygotsky tarafından ileri sürülen Kültürel Tarihsel Kuramın gelişim, oyun ve öğrenme konusundaki görüşlerini benimsemiştir. Buna göre gelişim, doğrusal olmayan bir karaktere sahiptir 
ve sosyal çevre ve kültür ile etkileşimin bir sonucudur. Ancak gelişimsel süreçte bazı evrensel insan özellikleri ve mekanizmalarının varlığı da kabul edilir. Ayrıca çocukların gücü ve kendi gelişimlerinin aktif üreticileri olduğu savunulur (Hakkarainen ve Bredikyte, 2010, 2014, 2018).

Anlatı oyun pedagojisinde oyun, Vygotsky'nin ileri sürdüğü şekilde gelişimsel ilerleme için kültürel araçların içselleştirildiği bir etkinlik olarak açıklanır. Ayrıca Kültürel Tarihsel Kuramın Vygotsky sonrası önemli araştırmacılarından biri olan Daniel Elkonin' in oyuna ilişkin görüşlerinin de anlatı oyun pedagojisinin teorik alt yapısını oluşturan temel taşlardan biri olduğu anlaşılmaktadır. Elkonin'in oyuna ilişkin görüşleri Leontyev'in ileri sürdüğü hakim etkinlik (leading activity) kavramına dayanmaktadır (Hakkarainen, 2010). Leontyev'e göre insan gelişimi hakim etkinlikler ile karakterize edilen aşamalara ayrılmıştır (Göncü, 2019). Her gelişimsel aşamada gelişimsel ilerlemelere neden olan hakim bir etkinlik türü vardır. Hakim etkinlikler, bireyin temel gelişimsel ilerlemelerine neden olur, diğer etkinlikler için temel sağlar, zihinsel süreçlerin yapılanmasında rol oynar. Yaşanılan kültürel bağlama göre farklılık gösterebilen hakim etkinlik türü; bebeklik döneminde (0-1 yaş aralığı) bakıcılarla duygusal etkileşim; yürümeye başlama döneminde (1-3 yaş aralığı) nesne yönelimli etkinlik; okul öncesi dönemde -mış gibi oyun; ilköğretimde öğrenme; ergenlik ve yetişkinlik döneminde ise ekonomik çalışma olarak sınıflandırılmıştır (Bodrova ve Leong, 2013). Elkonin'e göre hakim etkinlik türleri arasında geçiş, çocuk için yeni bir etkinliğe katılım ihtiyacı ve motivasyonu değişikliği oluşturduğu için gerçek bir zorluk ve gelişimsel bir krizdir. Elkonin, bu krizi her hakim etkinlik aşamasını iki alt döneme bölerek çözmüştür. Buna göre her hakim etkinliğin ilk aşaması araç geliştirme ve ikinci aşaması motivasyon dönemini içerir. Ancak hakim etkinlikler arası geçiş sürecinin ve eğitimin bu geçişleri desteklemedeki rolünün tartışmalı olduğu ifade edilir (Hakkarainen, 2010). Bu noktada Hakkarainen (2004) hakim etkinlikler arasındaki geçiş süreci için eski ve yeni hakim etkinlik türü (oyun ve okul öğrenimi) özelliklerinin birleşimini içeren "geçici etkinlik sistemini" önermiştir. Geçici etkinlik sisteminin amacı, hakim etkinlikler arasında geçişi desteklemek ve psikolojik krizin üstesinden gelmeyi sağlamaktır (Hakkarainen, 2010). Anlatı oyun pedagojisi geçişte bir müdahale uygulaması olarak ortaya atılmış ve özellikle iki kriz dönemine ( 3 yaşın krizi olan -mış gibi oyuna geçiş ve 7 yaşın krizi olan okul öğrenmesine geçiş) odaklanmıştır. Geçici etkinlik sistemi olarak anlatı oyun uygulamaları, hayali oyun dünyasını ve anlatılarla iç içe geçmiş gerçekçi problem çözme durumlarını içermektedir (Hakkarainen ve Bredikyte, 2018). Çocukların yetişkin desteği ile ortak bir hikâye kurgusunu deneyimlediği, "hayali, işbirliğine dayalı bir rol yapma etkinliği" olarak ele alınmaktadır (Bredikyte, ve diğerleri., 2017, s.11).

Anlatı oyun pedagojisinin temel aldığı bir diğer Kültürel Tarihsel Kuram görüşü, Vygotsky' nin yakınsak gelişim alanı (Zone of Proximal Development) kavramıdır. Bu doğrultuda çocuğun gelişimi ve öğrenmesini desteklemenin yolu olarak yakınsak gelişim alanı kavramı uygulamaya yansıtılmıştır (Hakkarainen, 2004; Hakkarainen, Bredikyte, Jakkula ve Munter, 2013). Vygotsky'e göre oyun çocuğun yakınsak gelişim alanını oluşturur. Çocuğun üst düzey performans göstermesi için etkili olan psikolojik araçları sağlar. Çocuklar oyun ortamında oyun dışı ortamlardaki gerçek beceri düzeylerinin üzerinde performans sergileyebilir (Bodrova ve Leong, 2013, 2015). Hakkarainen ve Bredikyte (2008) oyunda yakınsak gelişim alanı kullanımı için yeni yaratıcı oyun biçimlerini teşvik etme, oyun ortamları düzenleme, yeni zorlu oyun fırsatları sunma, çocuklara farklı aktiviteler arasında özgür seçim fırsatı sunma ve dolaylı yönlendirme gibi yöntemleri önermiştir.

Anlatı oyun pedagojisinin teorik alt yapısını oluşturan diğer görüşler arasında; Bruner'in anlatı zihin görüşü ve Lindqvist'in oyun dünyası kavramı öne çıkmaktadır (Bredikyte ve diğerleri., 2017; Hakkarainen ve Bredikyte, 2014). Bruner (1986) anlatının evrensel bir dil ve düşünce formu olduğunu savunur (Akt. Hakkarainen, 2008). "Kültürel-tarihsel bakış açısından, bir anlatı, insan düşünce ve bilgisini tematik birimlere dönüştüren ve birleştiren psikolojik bir araç olarak" tanımlanmıştır (Hakkarainen, ve diğerleri., 2013, s. 215). Anlatı oyun pedagojisine göre bellek süreçleri bireyin gözlemlerini öykü biçimine dönüştürür; böylece tek tek algılananlar yerine, hikayeler hatırlanır (Hakkairanen, 2010). Oyun ile birçok açıdan çeşitli benzerlikler taşıyan anlatılar, anlatı oyun projeleri için bir çerçeve olarak kullanılır. Burada söz konusu olan çocukların bir anlatı/hikaye sürecini canlandırmaları değil anlatı çerçevesinde sonu öngörülmeyen bir kurgu bağlamını deneyimleyerek kültürel araçlar edinmeleridir (Bredikyte ve diğerleri., 2017). Bu süreçte yetişkinler anlatı oyuna çocukların oyun ortağı olarak dahil olur. Çocuklar ve öğretmenler oyun dünyasını yaratmak için 
birlikte çalışırlar (Hakkarainen, 2008; Hakkarainen ve diğerleri, 2013). Lindqvist (1995) çocukların ve yetişkinlerin paylaştığı kurgusal dünya (bağlam) için "oyun dünyası" (playworld) kavramını kullanmıştır. Oyun dünyası; çocuklar ve yetişkinler tarafından ortaklaşa paylaşılan yaratıcı bir aktivitedir (Hakkarainen, 2008). Bir başka tanıma göre ise "oyun dünyası, kültürel deneyimlerini oyun etkinliklerine yansıtan yetişkinlerin çocukları yoğun olarak desteklendiği bir rehberlik şeklidir" (Baumer, Ferholt ve Lecusay, 2005, s.577).

Oyun dünyası uygulamalarında, gerçek dünyaya ilişkin problemler bir hikaye çizgisine gömülebilir. Böylece çocuklar macera bağlamında kurallara uyma, kod kırma, şifre çözme, yön bulma, harita çizme ve mektup yazma gibi çeşitli görevleri kolaylıkla yerine getirebilir. Ayrıca hikayelerde yer alan iyi-kötü, adilhaksız gibi zıtlıklar katılımcıları bu değerlerle ilgili düşünmeye yönlendirir. Oyun dünyalarındaki bu tür kültürel gerilimler, çocuklar için yaşamı anlamaya dair bir temel oluşturmakla birlikte değerleri tanımalarını da sağlar (Hakkarainen, 2010).

Anlatı oyun dünyasına girişte psikolojik araçların kullanıldığı belirtilmektedir. Bu psikolojik araçlar, klasik masallarda ve hikayelerde farklı dünyaların sembolik kapılarıdır. Bu kapıdan geçen kahraman gittiği dünyada farklı zorluklarla ve maceralarla karşılaşır (Hakkarainen, 2010). Çocukların ve yetişkinlerin oyun dünyasına girmesi, yeni kuralların ve rollerin yürürlüğe girdiği ve dramatik olayların yaşandığı hayali durumlar için bir tür sınırdan geçiştir (Lindqvist, 2003'den aktaran Fleer, Veresov ve Walker, 2020). Örneğin Lindqvist (1995), oyun dünyasına geçiş için bir uçan balon sepetine girme ve farklı ülkelere seyahat etme uygulamasını kullanmıştır. Anlatı oyun projelerinden birinde ise oyun dünyasına geçiş için "Narnia dolabı" isimli karton kutudan bir kapı kullanılmıştır. Çocukların Narnia oyun dünyasına gidip maceralar yaşamaları için "Narnia dolabı" olarak isimlendirilen bu kapıdan geçmeleri gerekir. Bu oyun projesi kış aylarında okulun yanındaki ormanda gerçekleştirilmiştir. Çocuklar önce Narnia dolabından geçip sonra okulun bahçe kapısından çıkarak Narnia oyun dünyasına geçmişlerdir (Hakkarainen ve Bredikyte, 2018).

Teorik ve felsefi temeller ışığında anlatı oyunun kavramsal olarak ayırt edici özellikleri olduğu söylenebilir. Buna göre anlatı oyunun temel özellikleri; sosyal/etkileşimli olması, hayal gücüne dayalı olması, yaratıcı olması, zamanla gelişmesi ve süresinin uzaması, zorlayıcı olması ve anlatı yapısına sahip olmasıdır (Bredikyte ve diğerleri, 2017). Bunun yanı sıra farklı yaş gruplarının bir arada uygulamalara katılması sağlanmaya çalışılır (Hakkarainen ve Bredikyte, 2018). Ek olarak özgür öğrenme deneyimleri içerir. Hakkarainen ve Bredikyte (2014) oyunda öğrenmeyi önceden belirlenmiş öğrenme hedefleri olmadığı için 'özgür öğrenme' olarak tanımlar. Geleneksel okullarda genellikle çocuklara kendi öğrenme deneyimlerini seçme fırsatı verilmez. Ancak anlatı oyun yaklaşımında çocuğun başlattığı uygulamaların değeri vurgulanır. Ayrıca öğrenme deneyimlerindeki zorluklar önceden belirlenmemiş ve mutlak ölçütler oluşturulmamıştır. Bu süreçte çocuklar hata yapmaktan korkmadan bireysel fikirlerini ifade edebilir ve anlatı oyun sürecine yön verebilirler (Bredikyte ve diğerleri, 2017; Hakkarainen ve Bredikyte, 2008, 2014).

\section{Anlatı Oyun Pedagojisinde Yetişkin}

Anlatı oyun pedagojisinde yetişkinler çocukların oyun ortakları olarak görülür. Anlatı oyun çerçevesinde çocukların oyununa dahil olur, çocukların fikirlerini gözlemler ve oyunu desteklemeye çalışırlar. Anlatı oyun pedagojisi uygulamaları, bir hikaye/anlatı ile çerçevelenir ve çocuklar ile yetişkinler oyunu oluşturmak için birlikte çalışır. Yetişkinler ve çocuklar birlikte temel temayı yapılandırır, oyun ortamlarını belirler ve roller üstlenirler (Hakkarainen ve Bredikyte, 2014, 2018). Anlatı oyun dünyasına birden fazla yetişkin -öğretmen, öğretmen adayları, araştırmacılar- farklı sorumluluklar üstlenerek dahil olabilir. Planlama, uygulama ve değerlendirme süreçleri boyunca öğretmen, öğretmen adayları ve araştırmacılar ekip olarak çalışır (Bredikyte ve diğerleri, 2017). Anlatı oyun pedagojisi sadece küçük çocukları destekleyen bir program olarak görülmez. Aynı zamanda öğretmen adaylarının çocukların dünyasını anlaması için bir araç olarak kullanılmıştır. Bu yolla öğretmen adaylarının gelişimsel destek sunma becerilerini, çocuklarla etkileşimlerini ve pedagojik yaratıcılıklarını geliştirmeleri hedeflenir. Pedagojik yaratıcılık, özellikle çocuğun yönlendirdiği programlar için önemli bir gerekliliktir. Eğitimciler pedagojik yaratıcılıklarını kullanarak çocukların gelişimine uygun destek sunma fırsatları yakalayabilirler (Hakkarainen ve Bredikyte, 2018). Öğretmen yeterliliklerini 
geliştirmek bu pedagojinin önemli bir yönü olarak görülür. Bu amaçla öğretmen eğitimi programıla bütünleştirilmiş lisans üstü eğitim ve yerel düzeyde hizmet içi eğitimlerin düzenlendiği ifade edilmiştir (Hakkarainen ve Bredikyte, 2010).

Anlatı oyun pedagojisinde yetişkinler öykü karakteri olarak, çocukla birlikte bir maceraya çıkan eşit oyun ortağı olarak veya oyun sürecinde gözlemci olarak anlatı oyuna katkı sağlayabilirler.

Öykü karakteri olarak yetişkin: Yetişkinler, anlatı içinde yer alan bir karaktere bürünerek oyun dünyasında rol alır. Anlatı oyun uygulamalarında yetişkin, bir karakter rolü oluştururken karaktere özgü şapkalar, kostümler, aksesuarlar kullanarak rolde olduğunu gösteren ipuçları kullanır. Öykü karakteri olarak rol alan yetişkinler, genellikle çocuklara yaklaşarak, yardım veya tavsiye isteyerek ya da onlara meydan okuyarak oyuna dahil olur. Karakter rolleri oluşturmak; anlatı oyun dünyasında sürekliliğin planlanması ve çocukların hem duygusal hem de fiziksel olarak anlatı oyun dünyası olaylarına dahil edilebilmesi açısından önemlidir. Öykü karakterleri, çocukların araştırması için bir dizi insani değeri ve psikolojik özellikleri temsil eder. Özellikle utangaçlık, kendini kontrol etme kuralları, sınırları zorlama, sorun çıkarma vb. davranışlar sergilenir. Böylece çocukların bu davranış ve değerlerle ilgili aynalama yapmasına katkı sağlanır. Yetişkinlerin hikaye karakteri olarak rol üstlenmesi; eğitim hedeflerine ulaşmak ve çocuklarla yeni etkileşim olanakları oluşturmak için kullanılabilecek güçlü bir eğitim aracı olarak görülür.

Maceracı veya oyun ortağı olarak yetişkin: Yetişkinler anlatı oyun projelerinde maceracı ya da oyun ortağı olarak da rol üstlenebilir. Bu yolla yetişkin çocukların oyuna motive olmasına, birbirleriyle ve rol karakterlerle iletişim kurmalarına, yaratıcı fikirler geliştirmelerine destek olurlar. Bununla birlikte çocukların düşüncelerini genişletmek için sorular yöneltebilir, yorum yapmalarını ve kendilerini ifade etmelerini teşvik edebilir ve çocukların öz düzenlemelerine yardımcı olabilirler. Ancak yetişkinler, oyun sürecinde soru sorarken sorularının oyun çerçevesinde olmasına ve yetişkin otoritesini çağrıştıran sorular olmamasına özen gösterir. Oyun ortağı olarak yetişkinin bir diğer önemli görevi anlatı oyun temalarında yer verilmiş olan çatışma durumunu ya da ahlaki problemi ortaya çıkarmaktır. Bunu dikkat çekici sorularla çocukları düşünmeye teşvik ederek yapabilir. Örneğin: "Tavşanın sorunu nedir? Neden böyle davranıyor? Ona nasıl yardımcı olabiliriz?". Bu sorular planlamada belirlenen eğitim hedefleri doğrultusunda kullanılır. Bununla birlikte soruların ortaya çıkardığı tartışmalar bir sonraki anlatı oyunların konularını belirleyebilir. Böylece çocukların anlatı oyun planlamasına dahil edildiği belirtilmektedir (Bredikyte ve diğerleri., 2017).

Gözlemci olarak yetişkin: Anlatı oyun projelerinde yetişkinlerin önemli rollerinden bir diğeri gözlemci olmaktır. Yetişkinler anlatı oyun projelerinde video kayıtları ve yazılı gözlemler yoluyla süreci belgeler. Anlatı oyun projelerinde gözlem hem oyun projelerine başlamadan önce hem de oyun sürecinde yapılır. Anlatı oyun projelerine başlamadan önce yapılan gözlemler çocukların ilgi ve ihtiyaçlarını belirlemek ve bu bilgileri anlatı oyun projeleri planlamalarına yansıtmak açısından önemlidir. Oyun sırasında yapılan gözlem ise çocuğun uygulamada gelişimsel durumunu ve ilerlemelerini takip etmek açısından gereklidir (Hakkarainen ve diğerleri., 2013).

Wood (2009)'a göre oyun pedagojilerinde yetişkinlerin önemli sorumlulukları oyun için ortam planlama, çocukların oyunlarını destekleme, çocuğun başlattığı ve yetişkinin yönlendirdiği etkinlikleri birleştirme, oyunda sürekliliği ve ilerlemeyi sağlamadır. Bu sorumlulukların anlatı oyun pedagojisinde yetişkinlerin üstlendikleri roller ile iş birliği içinde sürdürüldüğü anlaşılmaktadır. Anlatı oyun pedagojisinde yetişkinler öykü karakteri olarak, oyun ortağı olarak ya da gözlemci olarak çocukların fikirlerini genişletmeleri için etkili yollar sunabilir ve oyuna katkı sağlayabilir (Bredikyte ve diğerleri., 2017). Ayrıca anlatı oyun pedagojisinde yetişkinlerin pedagojik olarak güçlü ve yaratıcı olmaları uygulamalar için önem taşımaktadır (Hakkarainen, 2010; Hakkarainen ve Bredikyte, 2018). Bununla birlikte yetişkin imajının farklı uygulamalar ve yaklaşımlarda görülen yetişkin rollerinin bir birleşimini temsil ettiği de ifade edilebilir. Anlatı oyunlarda yetişkinlerin role girmesi yaratıcı dramadan (Adıgüzel, 2018) yararlanıldığını gösterirken oyun ortağı ve gözlemci rollerinin projeler boyunca aktif kullanılması Reggio Emilia yaklaşımı (Rinaldi, 2006) ile benzerlik göstermektedir. 


\section{Fiziksel Çevre}

Anlatı oyun pedagojisinde çevrenin çocuğu oyuna davet eden özellikler içermesine önem verilir. Çocuklar için oluşturulan ortamlarda özellikle farklı seçeneklerin çeşitliliği sağlanmaya çalışılır. Bunun için özel materyallere ve büyük bütçelere gerek duyulmaz. Çocuklar için güvenli olan her türlü malzeme oyun ortamı için kullanılabilir. Çeşitliliği sağlamak için mobilya parçaları, kutular, çubuklar, bloklar vb. gibi bazı esnek malzemeler sunulur. Böylece çocuklar bu parçalar ile gizli oyun alanları (örneğin; evler, kaleler, gizli kapılar, gemiler, trenler) yaratabilirler. Ayrıca koridorlar, tavan araları, salonlar, kiler gibi farklı alanlardan da yararlanılır. Bununla birlikte orman, park, bir tren, fabrika veya müze gibi okul dışı ortamların da anlatı oyun ortamı olarak kullanılabileceği belirtilmiştir. Çocukların çeşitli rolleri canlandırabilmelerine katkı sağlamak için ise çeşitli kumaşlar, aksesuarlar, maskeler, kostümler, şapkalar ve takılar gibi malzemeler sınıf ortamında bulundurulur. $\mathrm{Bu}$ malzemelerin çocukların yaratıcılıklarını kullanarak değiştirebilecekleri işlevsellikte olmasına dikkat edilir (Bredikyte ve diğerleri, 2017).

Oyun pedagojilerinde çocukların oyuna motive olmalarını sağlayıcı ortamların tasarlanması oldukça önemlidir (Wood, 2004). Çocuklara mümkün olduğunca doğal ve yapılandırılmamış oyun ortamları ve malzemelerinin sunulması onların sürekli yeni fikirler üreterek oyunlarını zenginleştirmelerini sağlar (Farne, 2005). Özellikle oyun kaynaklarının esneklik potansiyeline sahip olması çocuklara yeni kombinasyonlar ve değişiklikler yapma fırsatları sunar (Wood, 2009). Hatta çevrenin kendinden üretilen oyun malzemeleri (örneğin, su, toprak, ahşap vb.) çocukların kendi oyunlarını inşa etmelerine ve hayal güçlerini kullanarak gerçek şeylerle denemeler yapmalarına, maceralara çıkmalarına imkan tanır (Farne, 2005). Çocuklar zorlayıcı ve sürekli gelişen doğal oyun ortamlarını, öngörülebilir olan yapay oyun ortamlarına tercih eder (Zamani, 2016). Tüm bu ortam özelliklerinin yanı sıra çocukların oyun için yeteri kadar zamana ve özgür seçim fırsatlarına sahip olması da oldukça gereklidir. Çünkü çocukların failliğini (agency) -koşulları değiştirme özgürlüğü ve yeteneği- ortaya çıkaran ortamlar oyunu dönüştürücü güce sahiptir (Wood, 2004). Bu doğrultuda anlatı oyun pedagojisinde fiziksel çevrenin çocuğu oyuna motive edici unsurları içerecek şekilde düzenlenmeye çalışıldığı söylenebilir.

Anlatı oyun pedagojisi ilk olarak 2002 yılında Finlandiya Oulu Üniversitesi Kajaani kampüsünde "Silmu" isimli oyun araştırma laboratuvarında/kulübünde uygulanmaya başlanmıştır. Silmu oyun araştırma laboratuvarı; hem çocuklar ve aileler için yaratıcı bir oyun kulübü, hem öğretmen adayları için bir öğrenme ve araştırma alanı hem de üniversite araştırmacıları için çalışma alanı olarak kullanılmıştır. Bu laboratuvarın kampüs içinde ormanlık bir alanda küçük ve şirin bir binaya sahip olduğu ve binada araştırmacılar için bir oda ayrıldığı belirtilmiştir. Bunun dışındaki alanlar çocuklar için düzenlenmiştir. Çocuklar için ayrılan alan etkinlik merkezleri, bir mutfak ve bodrumdaki yaratıcı etkinlikler alanı şeklinde düzenlenmiştir. Çocuklar için sekiz köşe oluşturulmuştur. Bunlar; bloklar ve inşaat alanı, ev oyun alanı, hikaye okuma alanı, anlatma ve müzik alanı, tahta oyunları için bir alan, toplantı ve sanat alanı, el sanatları alanı, yaratıcı drama alanı ve mutfak. (Hakkarainen ve Bredikyte, 2018). "Silmu" oyun araştırma laboratuvarı, Finlandiya'da 2002-2010 yılları arasında anlatı oyun müdahaleleri için bir ortam olarak kullanılmış daha sonra Kajaani kampüsü'nün kapatılmasının ardından çalışmalara Litvanya' da Vilnius oyun laboratuvarında devam edilmiştir (Bredikyte ve diğerleri., 2017).

\section{Günlük Akış}

Anlatı oyun pedagojisi uygulamalarında günlük akış esnek bir biçimde sürdürülür. Ancak yine de örnek bir günlük akış mevcuttur. Anlatı oyun pedagojisi uygulamalarının gerçekleştiği oyun laboratuvarında yetişkinler saat 08: 00'de merkeze gelirler ve günlük hazırlıklarla ilgili çalışırlar. Çocuklar ise merkeze saat 09: 00'da gelir ve aktiviteler başlar. Saat 09: 00-09:30 arası özgür seçim/serbest zaman olarak ayrılmıştır. Saat 09:3010:00 arası sabah çemberi zamanıdır. Saat 10:00-10:30 arası hikaye sunumu gerçekleştirilir. Bu zaman diliminde yetişkinler drama kullanarak kuklalarla karşılıklı konuşmaya dayalı kukla gösterisi sunar. Saat 10:30-11:15 arası oyun zamanı, saat 11:15-11:45 arası öğle yemeği zamanı, saat 11:45-12:45 arası serbest oyun zamanı olarak belirlenmiştir. Saat 12:45-13:00 arası ise veda zamanı olarak ayrılmıştır. Çocuklar oyun zamanında özgür bir şekilde anlatı oyun uygulamalarına katılma ve serbest zamanda ise oyunlarını ve 
fikirlerini genişletme fırsatlarına sahiptir. Diğer taraftan programdaki zaman dilimlerinin oldukça esnek olduğu ve gün içinde gerçekleştirilen aktivitelerin akışına göre düzenlenebileceği belirtilmiştir. Gün içinde gerçekleştirilen aktiviteler ise; "rehberli büyük grup etkinlikleri, küçük grup halinde veya bireysel olarak başlatılan ve desteklenen etkinlikler, küçük gruplar halinde veya bireysel olarak serbest oyun etkinlikleri" şeklinde organize edilmiştir (Hakkarainen ve Bredikyte, 2018).

\section{Planlama, Uygulama ve Değerlendirme Süreci}

Anlatı oyun planlama, uygulama ve değerlendirme süreçlerine ilişkin oldukça açık ve detaylı bir çerçeve çizilmiştir. Planlama, uygulama ve değerlendirme süreçleri doğrusal bir zaman çizgisinde gerçekleşmez aksine bu süreçler iç içe geçmiştir. Aşağıda planlama, uygulama ve değerlendirme süreçleri açılanmıştır.

\section{Planlama}

Anlatı oyun pedagojisinde planlama esnek ve genel bir çerçeve ile yapılır. Genellikle sadece büyük grup anlatı oyun projeleri için detaylı planlama yapılır. Diğer aktiviteler doğaçlama ile yürütülür. Genel planlama şemasında tema, hikaye, projeler ve serbest oyuna ilişkin unsurlar göz önünde bulundurularak planlama yapılmaya çalışılır. Temalar, öğretmenlerin çocuk gözlemlerine dayalı olarak belirlenir genellikle küçük çocuklara uygun güvenlik ve tehlike, yardım ve arkadaşlık, korkularla baş etmek, kurallara uymak gibi temalar tercih edilir. Bu temalara ilişkin özellikler hikayelere gömülüdür. Anlatı oyunlar çocuklara hikaye sunumu ile başlar. Hikayeler anlatı oyun için giriş aracı, genel bütünleştirici bir çerçeve ve olaylar için bir bağlam yaratır. Çocukların hikayeye karşı ilgileri anlatı oyun planlamalarının başlangıcı için önemlidir. Bu nedenle çocukların ilgi ve gelişimsel özelliklerine uygun hikayelerin seçilmesi gerekir. Çocuklar, projelerle temayı anlamaya ve keşfetmeye yönelik özgürce seçebilecekleri ve yönlendirebilecekleri etkinliklere dahil olurlar. Farklı merkezlerde başlatılan ve desteklenen çeşitli aktivitelere katılabilir veya kendi fikirlerini geliştirebilirler. Anlatı oyun planlamasında önemi vurgulanan bir diğer unsur serbest oyundur. Serbest oyun için yeterince zaman ve alan oluşturularak yetişkinler ve çocuklar tarafından başlatılan faaliyetler arasında bir denge sağlanmaya çalışılır. Çocuğun başlattığı faaliyetlerin değerine vurgu yapılır ve özellikle serbest oyun faaliyetlerinin artması amaçlanır (Bredikyte ve diğerleri, 2017; Hakkarainen ve Bredikyte, 2014).

Alan yazın incelendiğinde çocuğun başlattığı etkinliklere özel bir vurgu olduğu görülmektedir (Schweinhart ve Weikart, 1988; Woods, 2017). Çocukların başlattı̆̆ı ve yetişkinlerin desteklediği etkinlikler gelişim ve öğrenme için etkili bir bağlam yaratır (Helavaara-Robertson, Barbour, Kinos, Pukk ve Rosqvist, 2015; Schweinhart, 1997). Diğer taraftan öğretmen müdahalesinin yoğun olduğu aşırı yapılandırılmış uygulamalara bağlılık çocukların başlattığı etkinliklerin ortaya çıkma olasılığını sınırlandırır. Bu nedenle planlama yaparken esnek bir yol izlenmesi ve çocuklara programı yönlendirmelerini sağlayacak özgür seçim imkanları sunulması önemlidir (Elkind, 2008; Gripton, 2017; Wood, 2014). Çocuğun başlattığı etkinlikler, özgür seçim, esnek planlama anlatı oyun pedagojisi planlamalarında öne çıkan özelliklerdir. Bu doğrultuda anlatı oyun pedagojisinin bu fikirleri eğitim ortamına yansıtacak, titizlikle hazırlanan bir planlama süreci olduğu düşünülebilir.

\section{Uygulama}

Anlatı oyun uygulamalarının amacı çocukların kendi kendine başlattı̆̆ı aktiviteleri ve gelişimsel geçişleri desteklemektir. Anlatılar yoluyla çocukların birbirleriyle ve kültürel araçlarla etkileşime girmesine ortam sağlanır (Hakkarainen ve Bredikyte, 2014). Bredikyte ve diğerleri, (2017) tarafından uygulama basamaklarını açıklayıcı rehber bir model önerilmiştir. Anlatı oyun uygulamaları başlangıcından sonuna kadar sürecin önemli dinamikleri; sürekli devam eden (1) hikayelerin araştırılması ve (2) gözlem, dokümantasyon, düşünme ve yansıtmadır. Uygulamalar, çocukların gelişimsel ilgi ve ihtiyaçlarının belirlenmeye çalışıldığ çocuk gözlemi ile başlar ve ilk hayali oyun denemeleri ile devam eder (Hakkarainen ve Bredikyte, 2020). Gerçek bir anlatı oyun projesine başlamadan önce, sınıfta düzenli olarak küçük rol oynama denemeleri gerçekleştirilir. Örneğin bir hikaye karakterinin (çocuklara sunulan bir hikayedeki kahramanın rolüne giren öğretmen adayı veya öğretmen) sınıfa gelerek çocuklarla sohbet etmesi, hayali durumlar yaratma ve ya hayali ortamlara geçme için ilk hayali oyun denemeleri olarak kullanılabilir. Bu ilk hayali oyun denemeleri anlatı oyun 
dünyasına giriş alıştırmaları olarak düşünülebilir. Yetişkinler bu süreçte çocukları gözlemler, verileri kaydeder ve bu veriler ekiple tartışılır. Elde edilen bulgular ışığında ilk hayali oyun denemelerini genişletmek için çevre değiştirme uygulamaları gerçekleştirir. Okul salonu, koridorlar, açı alanlar, orman, bahçe, çatı katı veya kiler gibi yeni ve farklı ortamlar kullanılabilir. Bir sonraki basamakta gerçek bir anlatı oyun projesi için ilk hikaye seçimi yapılır ve hikaye sunulur. Bunun ardından ilk anlatı oyun projesine başlanır. Hikayelerdeki ana olaylar anlatı oyun için çıkış noktasıdır. Ancak anlatı oyun bu ana olaylarla sınırlı değildir çocuklar oyunu özgürce yönlendirir ve yeni karakterler, olaylar ve ortamlar dahil edebilirler. Böylece hikayeden yola çıkarak yeni maceralara çıkar, problemlerle karşılaşır, bireysel veya grup olarak gelişimsel ilerlemelerini destekleyici görevlerle ve kültürel araçlarla etkileşime girerler. Çocukların heyecan verici bir maceraya çıkmalarını ve oyun projelerinin başlamasını sağlayan en önemli adım yetişkinlerin macerayı başlatan bir olay planlamalarıdır. Örneğin, sınıfa bir hikaye kahramanından veya yabancıdan mektup gelebilir; sınıfı bir hikaye kahramanı ziyaret edebilir; çocukların gizli bir planla veya çok garip bir çizimle karşılaşması sağlanabilir ya da okulda bilinmeyen bir geçit bulunabilir. Anlatı oyun projelerini başlatan bir olay gerçekleştikten sonra çocuklar toplanır ve tartışma başlatılır. Çocukların fikirleri anlatı oyunu yönlendirir (Bredikyte ve diğerleri, 2017). Örnek bir anlatı oyun projesinde öykü karakteri olarak rol alan yetişkin kralın sözcüsü rolünde sınıfa gelip kralın çocuklara gönderdiği mektubu tersten okumuştur. Bunun üzerine çocuklar toplanıp bunun anlamını çözmeye çalışmıştır. Çocuklar Surmindia krallığına bir büyü yapıldığını krallıktaki tüm odaların tersine çevrildiğini ve kralın yardım istediğini düşünmüştür. Buna göre çocukların bazı görevleri çözerek odaları normal haline getirmeleri gerekmektedir. Krallığa gidebilmek için ise ters yürüyüp, ceketlerini ters giyme ve tersten konuşma rutinini gerçekleştirirler (Hakkarainen, 2008). Anlatı oyun projesi uygulamalarında sadece ana olaydan yetişkinler sorumludur. Çocukların düşünmesi, tepki göstermesi, araştırması ve soru sorması için çocuklara fırsat verilir. Projeler kısa süreli veya uzun süreli olabilir. Projenin her uygulamasının ardından değerlendirme, yansıtma ve planlama yapılır. Çocuklara tartışmaları, soru sormaları ve hikayeler anlatmaları için fırsatlar verilir ve çizimler yoluyla yansıtma yapmaları desteklenir. Böylece oyun etkinliklerinin değerlendirilmesi yapılır ve daha fazla planlanma için çocukların tüm fikirleri toplanır. Son macera olan final uygulaması çocukların ortak yaratıcılığının bir sonucudur ve genellikle önceden öngörülemeyen bir durumdur. Proje sonunda anlatı oyun projesinin sonucu olarak çocuklarla birlikte karar verilerek bir rapor yazma veya bülten, fotoğraf albümü, video film, kitap, harita, sergi oluşturma gibi çeşitli etkinlikler yapılabilir. Sınıfta oyun projesini hatırlatan belli ürünlerin, işaretlerin veya sembollerin bulundurulması projenin özüne dikkat çektiği ve belirli projelere / hikayelere ilişkin sembolleri hatırlattı̆̆ için önerilmiştir (Bredikyte ve diğerleri, 2017).

Anlatı oyun pedagojisinde uygulama sürecinin yürütülmesinde hem çocukların fikirlerinin hem de yetişkinlerin uzmanlıklarının ve yaratıcılıklarının etkili olduğu anlaşılmaktadır. Uygulamaların çocuklar tarafından yönlendirilmesine izin verilmesi gelişim ve öğrenme için öngörülemeyen birçok fırsat yaratabilir. $\mathrm{Bu}$ süreçte yetişkinler çocuklara destek sunarak oyun ve öğrenme deneyimlerini zenginleştirebilir (Hakkarainen ve Bredikyte, 2018). Diğer taraftan anlatı oyunların birden çok yetişkin ile yürütülmesi, tek bir öğretmenin rehberlik ettiği sınıflarda uygulamanın kullanılması açısından zorluk oluşturabilir.

\section{Değerlendirme ve Dokümantasyon}

Anlatı oyun uygulamalarında süreç boyunca devam eden gözlem ve dokümantasyonun oyun projelerinin sürekliliğinin sağlanmasında önemli bir işlevi vardır. Gözlem, değerlendirme aracı olarak kullanılır (Hakkarainen ve Bredikyte, 2020). Gözlemler yetişkin ekibinde yer alan öğretmen adayları, öğretmen ve araştırmacılardan birkaçı tarafından yapılır. Gözlem verileri ile çocukların gelişimsel düzeyleri, ilgi ve ihtiyaçları belirlenmeye çalışılır ve çocuklar (bireysel veya grup) için eğitimsel hedefler oluşturulur. Gözlemler özellikle çocukların oyun girişimleri üzerine odaklanır. Çocuk oyunlarının konuları, bireysel olarak çocukların oyun becerileri, çocukların en sevdikleri oyun aksesuarı, oyun alanı, oyun arkadaşı vb. belirlenmeye çalışılır. Bununla birlikte grup atmosferi, çocukların etkileşimleri, birbirlerine karşı davranış biçimleri, gruptaki güç ilişkileri, mizaç türleri de uygulamalar boyunca gözlemlenir. Gözlemler; yazılı kayıtlar, video kayıtları ve çocuk günlükleri kullanılarak belgelenir. Çocuklar oyun deneyimlerini resimler, çizimler, yazılar, renklerle ya da biçimlerle ifade ettikleri günlüklerini eve götürebilir ve aileleriyle paylaşabilirler. Anlatı oyun 
pedagojisinde değerlendirme ve dokümantasyonun önemli bir boyutunu yetişkinlerin gözlemlerini yansıtmaları oluşturur. Anlatı oyuna eşlik eden yetişkin ekibinin gözlem verilerine ilişkin yorumlarını yansıtması ve tartışması profesyonel değerlendirme açısından önemli bir iş birliğidir. Değerlendirme, dokümantasyon ve yansıtmalar çocukların ilgi ve ihtiyaçlarını temel alan anlatı oyun etkinliklerinin planlanması için etkili bir kaynak oluşturur (Bredikyte ve diğerleri, 2017).

\section{Sonuç ve Tartışma}

Erken çocukluk dönemi; gelecek yaşantıların temellerinin atıldığı, çocuğun gelişim ve öğrenme potansiyelinin yüksek olduğu bir dönemdir. Bu dönemde çocukların potansiyelini desteklemeyi hedefleyen erken çocukluk eğitim hizmetlerinin gelişime ve çocuğun doğasına uygun olması, ilgi ve ihtiyaçları temel alması, çocuğun yaratıcılığını ve katılımını desteklemesi önemlidir (Bredekamp, 2015; Kostelnik, Soderman ve Whiren 2007). Bu çerçevede erken çocukluk eğitimine odaklanan tüm yaklaşımlar, alan uygulayıcıları ve uzmanları için çocuğun gelişimini desteklemeye yönelik farklı bakış açıları ve pedagojik araçlar sunar. Bu çalışmada Hakkarainen ve Bredikyte tarafından geliştirilen anlatı oyun pedagojisini tanıtıcı bir çerçeve çizilmeye çalışılmıştır. Anlatı oyun pedagojisinin öne çıkan özellikleri arasında; hakim etkinlikler arası geçişe müdahale, yetişkin çocuk oyun ortaklığına dayalı oyun dünyası uygulamaları, oyunda yakınsak gelişim alanının desteklenmesi, öğretmenin pedagojik yaratıcılığı, çocuğun yönlendirdiği oyun deneyimleri, farklı yaş gruplarının bütünleştirilmesi, tüm süreçte gözlem ve dokümantasyonun etkili kullanımı, çocuk, öğretmen ve öğretmen adaylarının etkileşimi olduğu görülmektedir. Geçici etkinlik sistemi olarak anlatı oyun çerçevesi, oyunun önemine yapılan vurgu ve yetişkinlerin anlatı oyunlarda üstlendiği roller anlatı oyun pedagojisinin alana önemli katkıları olarak düşünülebilir (Bredikyte ve diğerleri., 2017; Hakkarainen ve Bredikyte, 2014, 2018). Yapılan bir araştırmada anlatı oyun müdahalelerinden sonra çocukların oyun ve öz düzenleme becerilerinin artış gösterdiği belirlenmiştir (Bredikyte ve Hakkarainen, 2017). Ayrıca, çocukların anlatı oyun uygulamalarında korkuları yenme, problem çözme ve sosyal becerilerde ustalaşmak için sembolik araçları kullanmayı öğrendikleri görülmüştür (Hakkarainen, 2008). Bununla birlikte erken okuryazarlık becerilerine odaklanan bir anlatı oyun projesinde çocukların gelişimsel ilerlemeleri belgelenmiştir (Hakkarainen ve Vuorinen, 2018).

Anlatı oyun pedagojisinin Millî Eğitim Bakanlığı (MEB) (2013) okul öncesi eğitimi programı ile bazı benzer özelliklerinin olduğu söylenebilir. Çocuk merkezlilik, esneklik, keşfederek öğrenme, yaratıcılığın geliştirilmesi, değerlendirmenin çok yönlülüğü, kültürel ve evrensel değerleri benimseme iki programın benimsediği ortak özelliklerdendir. Ayrıca anlatı oyun pedagojisinde anlatıların çocuğun gelişimini destekleme için bir çerçeve olarak kullanılması MEB (2013) programının konuları amaç değil araç olarak kullanılması ile benzerlik göstermektedir. Buna göre anlatı oyun pedagojisinde anlatıların (Hakkarainen ve Bredikyte, 2014) Türkiye' de uygulanan okul öncesi eğitim programında ise konuların bir deneyim aracı olarak kullanılması hedeflenir (Bay, 2019; Gürkan, 2017).

Anlatı oyun pedagojisinde ileri düzey oyunlara -çocukların iş birliğine dayalı, yaratııı, sosyal rol yapma oyunlarına- özel bir vurgu yapılmaktadır. Okul öncesi dönemde ve ilkokula geçişte hayali oyunun gelişimsel ilerlemelere öncülük ettiği görüşü benimsenmiştir (Hakkarainen ve Bredikyte, 2018). Vygotsky "sembolik oyunu çocuğun gelişiminin lokomotifi" olarak görür (Vygotsky, 1998). Bu bağlamda anlatı oyun pedagojisinde çocukların oyunlarının zenginleştirilmesi hedeflenir (Hakkarainen ve Bredikyte, 2014). Yaşadığımız yüzyılda dijitalleşme, küreselleşme ve toplumsal yapının değişimi gibi çeşitli nedenlerden dolayı çocukların serbest oyunlarının önemli ölçüde azaldığına dikkat çekilmektedir (Elkind, 2008). Oysa sembolik oyun gelişime kaynaklık eder kültürel ve evrensel araçların kazanılması için ortam oluşturur (Bodrava ve Leong, 2013; Vygotsky, 1998). Bu bağlamda anlatı oyun pedagojisinde çocuğun yaratıcı oyunlarının desteklenmesine yapılan özel vurgunun önemli olduğu söylenebilir. Hakkarainen ve Bredikyte, (2020) sosyodramatik oyunun ciddi ölçüde azaldığı çağımızda oyun kültürünü geliştirmek için yaklaşımlarının bir yöntem olarak kullanılabileceğini vurgulamıştır. Bununla birlikte anlatı oyun uygulamalarının yetişkinin çocuğun oyununa katılımı üzerine kurulu olması programın işlevsel ve farklı bir yönü olarak düşünülebilir. Anlatı oyun uygulamalarında yetişkinler çocuğun oyun ortağı olarak, bir hikaye karakteri olarak ve gözlemci olarak 
aktif rol üstlenir. Diğer taraftan Türkiye'de Koçyiğit ve Başara Baydilek (2014) tarafından yapılan çalışmada çocuklar öğretmenlerin oyunlara katılmadıklarını ve evde de genelde yalnız oynadıklarını ifade etmiştir. Eğitimcilerin çocukların oyunlarına katılmamalarının nedeni oyunu geliştiren ve genişleten pedagojik stratejileri bilmemelerinden kaynaklanıyor olabilir. Anlatı oyun pedagoji uygulamaları bu konuda öğretmenler için yol gösterici örnekler sunabilir.

Anlatı oyun pedagojisinin önemli amaçlarından biri gelişimsel ilerlemenin üreticisi olan hakim etkinlikler arasındaki geçişi kolaylaştırmaktır. Bu doğrultuda özellikle okul öncesi döneminin hakim etkinliği olan oyun ve ilkokul döneminin hakim etkinliği olan öğrenme arasındaki geçiş anlatı oyun ile desteklenmeye çalışılır. Elkonin'in her gelişimsel aşaması araçların kullanımı ve motivasyon olmak üzere iki alt aşama içerir. Gelişimsel süreçte hakim etkinliklerin değişimi araç kullanımının ve motivasyon kaynağının değişimine neden olur. Bu durum çocuklar için kriz yaratır (Hakkarainen, 2004, 2010; Hakkarainen ve Bredikyte, 2018). Örneğin oyunun hakim etkinlik olduğu dönemde gerekli olan gelişimsel ilerlemeleri kazanan çocuklar, öğrenmenin hakim etkinlik olduğu döneme geçerler. Ancak bu çocukların problem çözme konusunda kullandığı zihinsel araçlar ve motivasyon kaynağı hala oyun odağındadır. Tam olarak bu noktada anlatı oyun yaklaşımının anlatı çerçevesinde gerçekçi problem çözmeye ve öğrenme görevlerine yer vermesi etkileyicidir. Anlatı oyun uygulamalarında çocuklar hayali bir dünya içinde problem çözmeyi deneyimler. Anlatı oyun çalışmaları okul öncesi eğitimde tüm etkinliklere özellikle Türkçe, drama, okuma yazmaya hazırlık ve oyun etkinliklerine uyarlanabilir ve uygulamalara yöntem çeşitliliği açısından katkı sağlar.

Anlatı oyun pedagojisi uygulamalarında bireysel ve grup olarak çocukların gelişimsel özellikleri, ilgi ve ihtiyaçları doğrultusunda planlama yapılır. Programda planlama esnek bir yapıdadır oyun alanlarının, gelişimsel ihtiyaçlara dayalı eğitim hedeflerinin ve yetişkinlerin süreçteki rollerinin düşünülmesini içerir. Bununla birlikte çocuğun başlattığı ve yönlendirdiği ileri düzey anlatı oyunların artış göstermesi hedeflenir. Böylelikle çocukların kendi gelişimlerinin üreticileri olmaları sağlanmaya çalışılır (Hakkarainen ve Bredikyte, 2010). Bredekamp (2015) etkili erken çocukluk eğitimi göstergelerinden birinin programda çocuğun başlattığ çalışmalara yer verilmesi olduğunu belirtmektedir. Benzer şekilde Elkind (2008) de çocuğun başlattığı oyuna değer veren erken çocukluk eğitim programlarının önemine dikkat çekmiştir. Bu doğrultuda anlatı oyun yaklaşımı çocuğun başlattığı oyunu destekleyen erken çocukluk eğitim uygulamalarının özgün ve farklı bir örneği olarak gösterilebilir. Etkili eğitim programlarının önemli unsurlarından biri gelişime uygun değerlendirme ve değerlendirmenin programa yansımasıdır (Bredekamp, 2015). Anlatı oyun pedagojisi uygulamalarında gözlem ve dokümantasyona kilit bir rol verilmiştir. Anlatı oyun uygulamalarının devam edebilmesi için sürekli gözlem ve dokümantasyon esastır. Gözlem sırasında elde edilen veriler daha sonraki uygulamaların planlamasına temel olur (Bredikyte ve diğerleri, 2017). Bu bağlamda değerlendirme sürecinin ve çocuğun yönlendirdiği oyunun anlatı oyun programının işlerliğinde etkili olan önemli iki mekanizma olduğu söylenebilir.

Anlatı oyun pedagojisinde farklı yaklaşımların izleri görülmektedir. Örneğin karma yaş gruplarının oluşturulması Montessori yaklaşımının farklı yaş gruplarının bir arada eğitimi özelliğine benzemektedir. Uygulamalarda farklı yaş gruplarının bir arada yer alması çocuk- çocuk etkileşimini hedeflemektedir. Böylece çocukların kendinden büyük akranlarla etkileşimi gelişime katkı sağlayabilir (Hakkarainen ve Bredikyte, 2018; Ulutaş ve Tutkun, 2016). Bununla birlikte anlatı oyun pedagojisinde Reggio Emilia yaklaşımından izler de görülmektedir. Anlatı oyun pedagojinin oyun ortamlarının özelliklerine ilişkin görüşlerinde Regio Emilia'dan esintiler görüldüğü söylenebilir. Farklı alanların oyun için kullanımı ve materyal çeşitliliğinin sağlanması her iki yaklaşımda da vurgulanmaktadır. Bununla birlikte her iki yaklaşımda da çevrenin organizasyonun etkileşim fırsatları sağlamada etkili olduğu belirtilmektedir. Anlatı oyun pedagojinde Reggio Emilia yaklaşımını hatırlatan diğer özellikler dokümantasyona ve yetişkinin çocuk ortaklığına yapılan vurgudur (Hakkarainen ve Bredikyte, 2018; Temel, Kurtulmuş ve İmir, 2016). Anlatı oyun yaklaşımında hikaye sunumları ve hikayelere verilen önem ise Waldorf yaklaşımıyla benzer özellikler olarak ifade edilebilir (Bredikyte ve diğerleri., 2017; Toran, 2016). Son olarak anlatı oyun pedagojisinde ileri düzey oyunun zenginleştirilmesine odaklanılmasının ise Zihnin Araçları Programı ile benzerlik gösterdiği söylenebilir (Bodrova ve Leong, 2013; Hakkarainen ve Bredikyte, 2018). 
Anlatı oyun uygulamalarında yaratıcı dramanın gücünden yararlanıldığı söylenebilir. Uygulama sürecinde temaların işlenmesi, süreç odaklılık, yaşantılardan öğrenme, yetişkinlerin hikaye karakterleri rolüne girmesi ve çocukların hayali dünyalara geçiş yapması yaratıcı drama uygulamalarında da görülmektedir (Adıgüzel, 2006a; Adıgüzel, 2006b; San, 2009). Diğer taraftan yaratıcı dramada yer alan tiyatro tekniklerinden yararlanma ve ısınma-canlandırma-değerlendirme aşamaları (Adıgüzel, 2010) anlatı oyun uygulamalarında kullanılmaz. Ancak yaratıcı dramanın değerlendirme aşamasında kullanılan yansıtma deneyimlerine benzer çalışmaların anlatı oyun projelerinin sonunda da gerçekleştirildiği görülür. Bunun yanı sıra yaratıcı drama için bir lider/yekişkin desteği yeterli iken (Adıgüzel, 2018) anlatı oyun bir yetişkin ekibi ile yürütülebilir. Anlatı oyun pedagojisinde hikayeler çocukların canlandırmalar yapması için bir araç olarak değil oyunu başlatan bir çerçeve olarak kullanılır. Anlatı oyun uygulamalarının temel amacı oyun ve öğrenme arasında bir köprü kurarak oyunun gelişimsel potansiyelini en üst düzeye çıkarmaktır (Bredikyte ve diğerleri., 2017; Hakkarainen ve Bredikyte, 2018).

Özetle anlatı oyun pedagojisi çocuğun gelişimi ve desteklenmesi hakkında birleştirdiği özgün fikirler ve ortaya koyduğu yeniklerle dikkat çekmektedir. Bu yaklaşımın teorik temelleri büyük bir titizlikle oluşturulmuş ve uygulamaya benzersiz bir şekilde yansıtılmıştır. Bu yaklaşım Türkiye'deki erken çocukluk eğitimi uygulamalarında önemli bir yol gösterici olabilir. Anlatı oyun yaklaşımı yüksek maliyetleri olan uygulamalar ya da materyaller içermez. Bu nedenle uygulamada kullanılması büyük zorluklar oluşturmaz. Yaklaşımın Türkiye'de kullanımı öğretmenin (öğretmen ve öğretmen adaylarının) mesleki gelişiminin desteklenmesi ile sağlanabilir. Bu doğrultuda Millî Eğitim Bakanlığı ve üniversiteler iş birliği yapabilir. Bu iş birliği öğretmenin desteklenmesini, öğretmen adaylarının sürece dahil edilmesini sağlayabilir. Son olarak yetişkinlere ve çocuklara anlamlı katkılar sağlayabilecek bir potansiyele sahip olan bu yaklaşımın araştırılması ve Türkiye'deki uygulamalara yansıtılması için çalışmalar yapılması önerilebilir.

\section{Yazar(lar)ın Beyanı}

Araştırmacıların katkı oranı beyanı: Bu çalışmanın tümü alan yazın taraması yapılarak ve yazarlar tarafından eşit katkı sağlanarak gerçekleştirilmiş̧ir.

Etik Kurul Kararn: Derleme bir çalışma olduğu için etik kurul kararı gerekmemektedir.

Çatışma beyanı: Araştırmada, yazarın kendi içinde ve diğer kişi/kurum/kuruluşlarla herhangi bir çıkar çatışması söz konusu değildir.

Destek ve teşekkür: Çalışmada herhangi bir kurum ya da kuruluştan destek alınmamıştır.

\section{Kaynaklar}

Adıgüzel, Ö. (2006a). Yaratıcı drama kavramı, bileşenleri ve aşamaları. Yaratıcı Drama Dergisi, 1(1), 17-30.

Adıgüzel, Ö. (2006b). Yaşantılara dayalı öğrenme, yaratıcı drama ve süreçsel drama ilişkileri. Yaratıcı Drama Dergisi, 1(1), 31-38.

Adıgüzel, Ö. (2010). Eğitimde Yaratıcı Drama. Ankara: Naturel.

Adıgüzel, Ö. (2018). Ĕğitimde yaratıcı drama. İstanbul: Yapı Kredi Yayınları.

Baumer, S., Ferholt, B., \& Lecusay, R. (2005). Promoting narrative competence through adult-child joint pretense: Lessons from the Scandinavian educational practice of playworld. Cognitive Development, 20(4), 576-590.

Bay, N. (2019). 36-72 aylık çocuklar için okul öncesi eğitim programı. S. Özbey \& S. Demiriz (Ed.) Okul öncesi eğitim programı (s. 96-126) içinde. İstanbul: Lisans.

Bodrova, E., \& Leong, D. J. (2015). Vygotskian and Post-Vygotskian Views on Children's Play. American Journal of Play, 7(3), 371-388.

Bodrova, E., \& Leong, D., (2013). Zihnin araçları: Erken çocukluk eğitiminde Vygotsky yaklaşımı. G. Haktanır (Çev. 
Ed.). Ankara: Anı Yayıncilık.

Bredekamp, S. (2015). Erken çocukluk eğitiminde etkili uygulamalar. H. Z. İnan \& T. İnan. (Çev. Ed.) Ankara: Nobel.

Bredikyte, M., \& Hakkarainen, P. (2017). Self-regulation and narrative interventions in children's play. T. Bruce, M. Bredikyte \& P. Hakkarainen (Ed) The Routledge international handbook of early childhood play (s. 246-257) içinde. New York: Routledge.

Bredikyte, M., Barrett, M., Brandišauskienè, A., Buivydienė, G., Chudy, S., Čepienė, R., ... \& Skerytė Kazlauskienè, M. (2017). Narrative environments for play and learning (NEPL) guidelines for kindergarten and school teachers working with 3-8 years-old-children. Vilnus.

Burdette, H. L., \& Whitaker, R. C. (2005). Resurrecting free play in young children: looking beyond fitness and fatness to attention, affiliation, and affect. Archives of pediatrics $\mathcal{E}$ adolescent medicine, 159(1), 46-50.

Elkind, D. (2008). Can we play? R., House. (Ed.), Too Much Too Soon?: Early learning and the erosion of childhood. (s.14-17) içinde. Hawthorn Press.

Farne, R. (2005). Pedagogy of play. Topoi, 24(2), 169-181.

Fleer, M., Veresov, N., \& Walker, S. (2020). Playworlds and executive functions in children: Theorising with the cultural-historical analytical lenses. Integrative Psychological and Behavioral Science, 54(1), 124-141.

Göncü, A. (2019). Oyunda Büyümek-Çocuk Gelişimi ve Eğitimine Sosyokültürel Bakış. İstanbul: Koç Yayınları

Gripton, C. (2017). Planning for endless possibilities. A. Wodds (Ed.) Child-initiated play and learning: Planning for possibilities in the early years (s. 8-22) içinde. New York: David Fulton.

Gürkan, T. (2017). Okul öncesi eğitim programlarının genel özellikleri ile kazanım ve göstergeler. A. Köksal Akyol (Ed.) Okul öncesi eğitim programları (s. 34-58) içinde. Ankara: Hedef.

Hakkarainen P., Bredikyte, M., Jakkula, K. \& Munter, H. (2013). Adult play guidance and children's play development in a narrative play-world, European Early Childhood Education Research Journal, 21(2), 213-225.

Hakkarainen, P \& Vuorinen, M. L. (2018). The Program of Developmental (Narrative) Play Pedagogy. M. Fleer \& B. van Oers (Ed.) International Handbook of Early Childhood Education. (s. 251-268) içinde. Dordrecht: Springer.

Hakkarainen, P. (2004). Narrative learning in the fifth dimension. Critical Practice Studies, 6(1), 5-20.

Hakkarainen, P. (2008). The challenges and possibilities of a narrative learning approach in the Finnish early childhood education system. International Journal of Educational Research, 47(5), 292-300.

Hakkarainen, P. (2010). Culturalhistorical methodology of the study of human development in transitions. Cultural-Historical Psychology, (4), 75-82.

Hakkarainen, P., \& Bredikyte, M. (2008). The zone of proximal development in play and learning. Cultural Historical Psychology, (4), 2-11.

Hakkarainen, P., \& Bredikyte, M. (2010). Strong foundation through play-based learning. Psychological Science E Education, (3), 58-64.

Hakkarainen, P., \& Bredikyte, M. (2014). Understanding narrative as a key aspect of play. L. Brooker, M. Blaise, S. Edwards (Ed). The Sage Handbook of Play and Learning in Early Childhood (s. 240-251) içinde. London: Sage.

Hakkarainen, P., \& Bredikyte, M. (2018). The Program of Developmental (Narrative) Play Pedagogy. M. Fleer \& B. van Oers (Ed.) International Handbook of Early Childhood Education (s. 1041-1058) içinde. Dordrecht: Springer.

Hakkarainen, P., \& Bredikyte, M. (2020). Playworlds and Narratives as a Tool of Developmental Early 
Childhood Education. Psychological Science and Education, 25(4), 40-50.

Helavaara Robertson, L., Kinos, J., Barbour, N., Pukk, M., \& Rosqvist, L. (2015). Child-initiated pedagogies in Finland, Estonia and England: exploring young children's views on decisions. Early Child Development and Care, 185(11-12), 1815-1827.

Koçyiğit, S., \& Baydilek, N. B. (2015). Okul öncesi dönem çocuklarının oyun algılarının incelenmesi. Yüzüncü Yil Üniversitesi Eğitim Fakültesi Dergisi, 12(1), 1-26.

Kostelnik, M. J., Soderman, A. K., Whiren, A. P. (2007). Developmentally appropriate curriculum. New Jersey: Pearson Education.

Lindqvist, G. (1995). The aesthetics of play: A didactic study of play and culture in preschools. Stockholm: Almqvist \& Wiksell.

Miller, E., \& Almon, J. (2009). Crisis in the kindergarten: Why children need to play in school. College Park, MD: Alliance for Childhood, Maryland.

Milli Eğitim Bakanlığı, (2013). Okul öncesi eğitimi programı. Ankara: Devlet Kitapları Basım Evi.

Rinaldi, C. (2006). In dialogue with Reggio Emilia: Listening, researching, and learning. New York: Routledge.

Rogers, S. (Ed.) (2010). Rethinking play and pedagogy in early childhood education: Concepts, contexts and cultures. New York: Routledge.

Ryan, S., \& Northey-Berg, K. (2014). Professional preparation for a pedagogy of play. L. Brooker, M. Blaise, S. Edwards (Ed.) The SAGE handbook of play and learning in early childhood, (s. 204-215) içinde. Los Angeles, CA: Sage.

San, İ. (2009). Ne zaman eğitimde yaratıcı drama ne zaman tiyatro/drama?. Yaratıcı Drama Dergisi, 4(7), 5-14.

Sandberg, A., \& Pramling-Samuelsson, I. (2003). Preschool teachers' play experiences then and now. Early Childhood Research and Practice, 5(1),373-395

Schweinhart, L. J. (1997). Child-initiated learning activities for young children living in poverty. Clearinghouse on Elementary and Early Childhood Education. EDOPS-97-23.

Schweinhart, L. J., \& Weikart, D. P. (1988). Education for young children living in poverty: Child-initiated learning or teacher-directed instruction?. The Elementary School Journal, 89(2), 213-225.

Temel, Z. F. Kurtulmuş, Z. \& İmir, H. M. (2017). Reggio Emilia yaklaşımı ve uygulamalar. Z. F. Temel (Ed.) Okul öncesi eğitimde alternatif yaklaşımlar (s. 104-128) içinde. Ankara: Hedef Yayıncılık.

Toran, M. (2017). Steiner pedagojisi ve Waldorf okulları. Z. F. Temel (Ed.) Okul öncesi eğitimde alternative yaklaşımlar (s. 14-37) içinde. Ankara: Hedef Yayıncılık.

Tuğrul, B., Metin Aslan, Ö., Ertürk, H. G., \& Özen Altınkaynak, Ş. (2014). Anaokuluna devam eden altı yaşındaki çocuklar ile okul öncesi öğretmenlerinin oyun hakkındaki görüşlerinin incelenmesi. İnönü Üniversitesi Eğitim Fakültesi Dergisi, 15(1), 97-116.

Ulutaş, İ. \& Tutkun, C. (2017). Montessori eğitim yöntemi ve uygulama örnekleri. Z. F. Temel (Ed.) Okul öncesi eğitimde alternatif yaklaşımlar (s. 40-67) içinde. Ankara: Hedef Yayıncılık.

Vygotsky, L. S. (1998). Düşünce ve Dil. (Çev. S Koray). İstanbul: Toplumsal Dönüşüm Yayınları

Wood, E. (2004). Developing a Pedagogy of Play for the 21st century. A. Anning, J. Cullen, M. Fleer (Ed.), Early childhood education: Society and culture (s. 17-30) içinde, London: Sage.

Wood, E. (2009). Developing a Pedagogy of Play. A. Anning, J. Cullen, \& M. Fleer. (Ed). Early Childhood Education: Society and Culture (s. 27-38) içinde. London: Sage. 
Wood, E. A. (2014). Free choice and free play in early childhood education: Troubling the discourse. International Journal of Early Years Education, 22(1), 4-18.

Woods, A. (Ed.). (2017). Child-initiated play and learning: planning for possibilities in the early years. Taylor \& Francis.

Zamani, Z. (2016). 'The woods is a more free space for children to be creative; their imagination kind of sparks out there': exploring young children's cognitive play opportunities in natural, manufactured and mixed outdoor preschool zones. Journal of Adventure Education and Outdoor Learning, 16(2), 172-189. 


\section{EXTENDED ABSTRACT}

\section{Introduction}

The foundations of future lives are constructed in early childhood when development and learning potential are at their highest levels. Early childhood education services aiming to actualise the promise and aptitudes of children must be apposite to the nature and growth phase of individual children. Pedagogic practices must support the child's creativity and participation and consider a child's personality, interests and needs (Bredekamp, 2015; Kostelnik et al., 2007). All approaches to early childhood education purpose to support the development of children and offer distinct perspectives and pedagogical tools for teachers and researchers. This study introduces narrative play pedagogy, a method developed in Finland to preserve the power of play and support adult-child partnerships. It attempts to design a conceptual framework encompassing the theoretical and philosophical foundations of the approach, the educational environment, roles discharged by adults, daily flow, planning, implementation and evaluation process.

\section{Theoretical and Philosophical Foundations}

Hakkarainen and Bredikyte developed narrative play pedagogy in the late 1990s. In essence, this methodology is theoretically and philosophically grounded in Vygotsky's cultural-historical theory of development and the ideas expressed by Professor Vasili Davydov and his team (Hakkarainen ve Bredikyte, 2018). Vasili Davydov and his team members identified preschool education centred on the developmental and educational needs of young children. Professor Davydov engaged in group discussions with his team members to ascertain the need to create a world for children in preschool education institutions and to determine ways in which such spaces could be constructed (Hakkarainen \& Bredikyte, 2020). He questioned the developmental potential of play and sought ways to maximise its possibilities (Hakkarainen \& Bredikyte, 2018). The narrative play pedagogical approach began as an attempt to resolve the theoretical and analytical problems mooted by Davydov and his team (Hakkarainen \& Bredikyte, 2020). The method aimed to devise children's play activities and to facilitate the transition between playing and school learning tasks. In narrative play practices, narratives are used as the framework promoting socio-dramatic play initiated and directed by the child. Narratives enrich children's play and provide a context that includes cultural tools. Children do not enact the narrative/story process. They acquire cultural tools by experiencing an unforeseen fictional context within the narrative framework (Bredikyte et al., 2017).

\section{Essential Elements of Narrative Play}

Narrative play is a social/interactive activity based on imagination and creativity. It develops over an extended time, is compelling and encompasses a storytelling structure (Bredikyte et al., 2017). Efforts are also made to ensure the collaborative participation of different age groups (Hakkarainen \& Bredikyte, 2018). Hakkarainen and Bredikyte (2014) defined learning in play as 'free learning' because no predetermined learning goals are established. Children in traditional schools are usually not accorded opportunities of selecting their own learning experiences. However, the narrative play approach emphasises the value of childinitiated activities. Further, no absolute criteria or difficulty levels are prescribed for the learning experiences that occur through this pedagogy. Instead, children can express individual opinions and direct the narrative play process without fear of making mistakes.

\section{Physical Environment}

Practices are carried out in a variety of in-school and out-of-school environments that invite the child to play. Narrative play pedagogy was first introduced in 2002 in Silmu, a play research laboratory at the Kajaani campus of Oulu University in Finland. The Silmu play research lab was designated a creative play club for children and families, a learning and research area for students and a workplace for university researchers (Hakkarainen \& Bredikyte, 2018; Bredikyte et al., 2017).

\section{Adult Roles}

In narrative play pedagogy, adults are viewed as the play partners of children. They engage in play with 
children within the framework of the narrative play, observe the children's ideas and try to support the activity. Generally, teachers and trainee educators represent the adults involved in the narrative play world. Adults may participate in the narrative play as story characters, as equal play partners on an adventure with the child or as observers of the play process. Adult teams endeavour to improve the children's play by observing, documenting and reflecting on the entire application (Bredikyte et al., 2017). Narrative play pedagogy does not merely support young children; prospective teachers can also employ this tool to understand the world of children. Trainee teachers can hone their developmental support skills, their interactions with children and their pedagogical creativity using this method. Pedagogical creativity is vital, especially for child-led programmes. Educators can use their pedagogical creativity to discover opportunities that can help them offer appropriate support for the development of children (Hakkarainen \& Bredikyte, 2018). The refinement of teacher competencies is an important aspect of this pedagogy. Thus, scholars recommend its inclusion in graduate education and integration into teacher-training in-service training programmes. (Hakkarainen \& Bredikyte, 2010).

\section{Planning, Implementation and Evaluation}

Narrative play pedagogy adopts dynamic and flexible planning, implementation and evaluation cycles. Planning is performed within a variable and general framework. Generally, only large-group narrative play projects are planned in detail. Other activities are improvised. The general planning scheme considers elements related to the theme, story, projects and free play. Children direct the narrative play during the implementation process, while adults following the leadership of the children as they attempt to enrich the play and bolster the development of the youngsters. The sustained observation and documentation process that is applied throughout the narrative play practice is pivotal to the assurance of the continuity of play projects (Hakkarainen \& Bredikyte, 2018; Bredikyte et al., 2017).

\section{Conclusion and Discussion}

The narrative play pedagogy attracts attention because of its originality and the innovations it offers in helping children develop their skills and potentials. The theoretical foundations of this approach have been carefully crafted, and its application is distinctively cognised. This unique approach can serve as an apt guide for the early childhood education methodologies applied in Turkey. Digitalisation has now significantly transformed children's play; narrative play pedagogy offers a framework for its enrichment. Hakkarainen and Bredikyte (2020) highlighted that their approach could be used as a method of inculcating a contemporary play culture at a time when socio-dramatic play evinces severe decline. The fact that narrative play practices are founded on adult participation in child-directed play is also a functional and original aspect of this pedagogy. 